\title{
EVALUATION OF ANTIOXIDANT, PHYTOCHEMICALS AND ANTIBACTERIAL POTENTIAL OF Mormordica charantia (Linn) AGAINST PATHOGENIC BACTERIA ISOLATED FROM READY TO EAT FOOD SOLD IN AKURE METROPOLIS, NIGERIA
}

\author{
Tope Abraham Ibisanmi ${ }^{*}$, Jamiu Olaseni Aribisala ${ }^{I}$
}

Address (es):

${ }^{1}$ Department of Microbiology, School of Sciences, Federal University of Technology, P.M.B. 604, Akure, Ondo state, Nigeria, phone: +2348104091709 .

*Corresponding author: topeibisanmi@gmail.com

ABSTRACT

https://doi.org/10.36547/be. 389

Introduction: M. charantia (Linn) is a medically important vine, annual to perennial monoecious climbing or sprawling herb.

Objecive: This study was carried out to evaluate the antioxidant, phytochemicals and antibacterial potential of Mormordica charantia (linn) against pathogenic bacteria isolated from ready to eat food.

Method: Bacteria species were isolated and identified from Ready-to-eat (RTE) food using standard method, antioxidant, antibacterial sensitivity pattern, extraction and antimicrobial activity was determine using standard microbiological method.

Results: Bacteria isolated from RTE food studied belong to the following genera; Staphylococcus, Streptococcus, Citrobacter, Pectobacterium, Klebsiella, Bacillus, Kocuria, Kluyveria, Serratia, Pantoea, Enterobacter and Salmonella. The antibiotic susceptibility pattern shows Gentamycin $(30 \mu \mathrm{g})$ to have great inhibitory activities against most Gram negative isolates while Streptomycin $(30 \mu \mathrm{g})$ showed great inhibitory activities against most Gram positive isolates. Water and ethanol extracts showed significant to moderate antibacterial activity toward all tested isolates except; Escherichia vulneris and Kluyveria intermedia which are less susceptible to water extracts whereas Kluyveria intermedia is less susceptible to ethanol extracts. The highest inhibitory activity was observed for Bacillus cereus with zone of inhibition of diameters $28 \pm 0.29^{\mathrm{l}}(\mathrm{mm})$, followed by Escherichia vulneris $25 \pm 0.29^{\mathrm{l}}(\mathrm{mm})$. DDPH\% Inhibition has higher value in the water extract $\left(69.21 \pm 0.882^{\mathrm{a}}\right)$ while lower value was recorded in the ethanol extract $\left(67.89 \pm 0.155^{\mathrm{b}}\right)$. \% Iron chelation has higher value in the ethanol extract $\left(121.87 \pm 0.882^{\mathrm{a}}\right)$ while lower value was recorded in the water extract $\left(97.28 \pm 0.155^{\mathrm{b}}\right)$. In all the concentration, vitamin $\mathrm{C}$ was higher in the ethanol extract than in the water extract.

Conclusions: The study revealed that all the Ready-to- eat food had a total bacterial count that are below potentially hazardous count although the presence of some microorganisms that are of health significance were observed. The study also confirmed that $M$. charantia (Linn) extracts had antibacterial effect against tested isolates from Ready-to -eat food sold in Akure metropolis. Based on the findings of this great research work, Mormordica charantia (Linn) possesses antioxidant activity that could prevent oxidative stress and degenerative diseases.

Keywords: Antibacterial, Mormordica charantia (Linn), pathogenic bacterial, read-to-eat food, antioxidant, phytochemical

\section{INTRODUCTION}

Man's life and survival would be impossible without 'symbiosis' with, and extensive use of plants and plant products. plants have been a valuable source of natural products for maintaining human health, especially in the last decade, with more intensive studies for natural therapies (Boklage and Lehmkuhl, 2018). According to the World Health Organization "a medicinal plant" is any plant which in one or more of its organ contains substances that can be used for the therapeutic purposes or which are precursors for the synthesis of useful drugs (Awuchi, C., 2019).

Medicinal plants have become the subject of very intense pharmacological study in recent years (Ahn, 2017). The continuous emergence multidrug resistances microorganisms has drastically reduces the efficacy of our antibiotic armory, and consequently, increases the frequency of therapeutic failure (Olusola-makinde $\boldsymbol{e t}$ al.., 2021; Awuchi, C., 2019). Although, hundreds of plant species have been screened and tested for antimicrobial properties, the vast majority of the plants have not been adequately screened and evaluated. Considering the vast potentiality of plants as sources for antimicrobial drugs, the present research aimed to carryout phytochemical screening and evaluates Mormordica charantia (Linn) for antimicrobial activity on pathogenic bacteria from RTE food sold in Akure metropolis.

M. charantia (Linn) is an annual to perennial monoecious climbing or sprawling herb. It may be either hairless or slightly hairy. There is a central taproot, from the apex of which the stems spread to climb over any available support (Deepti $\boldsymbol{e t}$ al., 2017). M. charantia (Linn) is a medically important vine (Khalid et al., 2021). It has also been utilized in different traditional medicines for the treatment of bronchitis, cholera, anemia, ulcer, blood diseases, diarrhea, gonorrhea rheumatism, gout, colic, worms, dysentery, disease of liver and spleen, cancer and diabetes etc. (Jandari et al., 2020). The main constituents of this plant include protein, triterpene, alkaloid, steroid, inorganic, lipid, and phenolic compounds, which are responsible for biological and pharmacological activities such as anti-diabetic, anti-cancerous and anti-tumorous, anti-microbial, anti-helmintic, antimalarial, anti-ulcerative and immunomodulatory (Guarniz et al., 2019).

The food eaten has a direct influence on health, it is therefore an important task for food inspectors, food manufactures and food handlers to keep food safe from pathogenic microorganisms, especially when such food are to be consumed without further processing (Banik, 2019), some ready-to-eat foods also are regarded as 'potentially hazardous'. Such foods can support the growth of pathogenic (food poisoning) bacteria and must be kept at certain temperatures to minimize the growth of any pathogens that may be present in the food or to prevent the formation of toxins in the food (NSW, 2019) Foodborne diseases due to bacteria occur with the consumption of food contaminated by pathogen microorganisms (Mboto et al., 2012). At present, the spectrum of foodborne diseases is increasing and these diseases create a major health problem. Different foodborne pathogens have been associated with outbreaks of foodborne disease The continuous emergence of multidrug resistances microorganisms have drastically reduced the efficacy of our antibiotic armory, and consequently, increases the frequency of therapeutic failure. The food eaten has a direct influence on health, it is therefore an important task for food inspectors, food manufactures and food handlers to keep food safe from pathogenic microorganisms, especially when such food are to be consumed without further processing. At present, the spectrum of foodborne diseases is increasing and these diseases create a major health problem. Hence this study would determine the antibacterial activity of $M$. charantia (Linn) on pathogenic organism from Ready-to-eat food sold in Akure metropolis.

\section{Aim and Objectives}

The aim of this study is to evaluate phytochemicals and detemine the antibacterial activity of M. charantia (Linn) on pathogenic organism from Ready-to-eat food sold in Akure metropolis.

The specific objectives of the study are to;

i. isolate and characterize bacteria from Ready-to-eat food sold in Akure metropolis;

ii. evaluates the quantitative and qualitative phytochemicals of $M$. charantia (Linn) extracts;

iii. determine the antibiotics sensitivity pattern and antibacterial activity of $M$. charantia (Linn) extract against pathogenic bacteria isolated from Ready-toeat food sold in Akure metropolis and 
iv. evaluate the minimum inhibitory concentration and minimum bactericidal concentration of the extract on pathogenic bacteria isolated from Ready-toeat food sold in Akure metropolis.

\section{MATERIALS AND METHODS}

\section{Plant Sample}

The plant $M$. charantia (Linn) selected for this study was collected along the school farm of Federal University of Technology, Akure, Ondo state, Nigeria $\left(7.2571^{\circ} \mathrm{N}\right.$, $5.2058^{\circ} \mathrm{E}$ ). The plant material used was identified at the herbarium in Crop, Soil And Pest Management Department.

\section{Food Samples}

Ready to eat food samples were collected for 30 days. A total of 103 samples were transferred from different vendor to the microbiology laboratory aseptically. The samples consisted of white rice, moimoi, fried rice and suya.

\section{Other Materials}

test tubes, conical flasks, sterile syringes, wire loops, sterile disposable Petri dishes, beaker, autoclave, incubator, cover slip, microscope slide, plain bottles, weighing balance, cotton wool, ethanol, paper tape, measuring cylinder, hand gloves, distilled water, Bunsen burner, refrigerator, test tube rack, retort stand, thermometer, burette, $\mathrm{pH}$ meter, bioreactor and anaerobic jar.

\section{Sterilization of materials}

All materials were washed the detergent and rinsed thoroughly. They were placed in a rack to dry and then autoclaved at $121^{\circ} \mathrm{C}$ for 15 minutes to kill microorganisms.

\section{Preparation of Plant Materials for Extraction}

The plant materials were dried (in a ventilated room away from direct sun light) for 28 days. The dried pieces (whole plant) were milled into powdery form using a mortar and pestle, and put in a container. The weights of the powdered form of leaves were recorded.

\section{Preparation of Ethanol Extract}

Two hundred and fifty grams $(250 \mathrm{~g})$ of the powdered plant materials were weighed and soaked in one thousand two hundred and fifty $(1250 \mathrm{ml})$ of Ethanol and kept for 72 hours in a Gallenkamp shaker at 65 revolutions per minute. The contents were sieved using muslin cloth, the liquid sieved was then filtered by pouring the contents sieved into a beaker containing a funnel and Whatman filter paper no. 1 inserted into it. The filtrate was poured into a round bottom flask and kept away from direct sunlight undisturbed, thereafter it was subjected to further extraction using soxhlet apparatus for subsequent sterile filtration and filtrate oven dried at $40{ }^{\circ} \mathrm{C}$ till it became paste-like in appearance. The paste-like filtrate was weighed and stored in the refrigerator at $4{ }^{\circ} \mathrm{C}$ until used. The crude extract was thereafter weighed and dissolved in a known volume of dimethyl sulphoxide.

\section{Preparation of Water Extract}

Two hundred and fifty grams $(250 \mathrm{~g})$ of the powdered plant materials were weighed and soaked in one thousand two hundred and fifty $(1250 \mathrm{ml})$ of distilled water and kept for 72 hours in a Gallenkamp shaker at 65 revolutions per minute. The contents were sieved using muslin cloth, the liquid sieved was then filtered by pouring the contents sieved into a beaker containing a funnel and Whatman filter paper inserted into it. The filtrate was poured into a round bottom flask and kept away from direct sunlight undisturbed, thereafter it was subjected to further extraction using soxhlet apparatus for subsequent filtration and filtrate oven dried at $40^{\circ} \mathrm{C}$ till it becomes paste-like in appearance. The paste-like filtrate was weighed and stored in the refrigerator at $4{ }^{\circ} \mathrm{C}$ until used. The crude extract was thereafter weighed and dissolved in a known volume $(10 \mathrm{ml})$ of dimethyl sulphoxide.

\section{Isolation of Bacteria}

Bacteria isolation was carried out using the pour plate technique. $0.1 \mathrm{ml}$ of serial diluents $10^{-2}$ and $10^{-4}$ was measured and poured into different sterile Petri dishes respectively and it was then overlayed with the molten sterilized Nutrient agar (NA) media, this was also done for MacCokay agar, Salmonella-Shigella agar, Mannitol salt agar and Eosine methylene blue agar. The plates were rocked gently to ensure homogeneity on the media in the plates and were then allowed to solidify. After solidification, the plates were then incubated aerobically in the incubator at $37^{\circ} \mathrm{C}$ for 24 hours. Pure cultures of the microorganisms were obtained using the streak plate method. Distinct colonies were examined and enumerated. Identification of bacterial isolates was performed according to standard bacteriological techniques previously established

\section{Antibacterial Assay}

The effect of the plant extracts on the bacterial strain was assayed by Agar well diffusion method and further confirmed by Disc diffusion method. Agar well diffusion method was used to test the antibacterial activity of the extracts. The bacteria inoculi were prepared by transferring the isolates from already incubated Nutrient Agar into a freshly prepared broth using inoculating loop and incubated for 24 hours at $38^{\circ} \mathrm{C}$. After incubation, standardized inoculum was streaked on petri dishes containing freshly prepared Muller Hinton Agar using a sterile swab sticks.five $6 \mathrm{~mm}$ wells were bored on the already inoculated MHA plates using a sterile cork borer, the susceptibility test was carried out in triplicate. Each of the wells were filled up with $100 \mathrm{mg} / \mathrm{ml}, 50 \mathrm{mg} / \mathrm{ml}$ and $25 \mathrm{mg} / \mathrm{ml}$ of the reconstituted extracts respectively. The fourth well, being the positive control was filled up with $25 \mathrm{mg} / \mathrm{ml}$ Chloramphenicol while $2 \%$ DMSO was used as the negative control. The plates were incubated at $38^{\circ} \mathrm{C}$ for 18 to 28 hours and zones of inhibition were measured with millilitre ruler.

\section{Evaluation of Minimum Inhibitory Concentration and Minimum Bacteriocidal Concentration}

For minimium inhibitory concentration, $0.2 \mathrm{ml}$ of extract $(100 \mathrm{mg} / \mathrm{ml}, 50 \mathrm{mg} / \mathrm{ml}$ and $25 \mathrm{mg} / \mathrm{ml}$ ) was dispense into different bottles containing standardized organism suspension. The bottles were incubated at $38^{\circ} \mathrm{C}$ for 24 hours after which turbidity was measure using spectrophotometer. For minimium bacteriocidal concentration, $1 \mathrm{ml}$ of aliquots of test organism suspension from the minimiun inhibitory concentration test bottles was pour plate into a fresh culture media after, incubated at $38^{\circ} \mathrm{C}$ for 24 hours.

\section{Phytochemical Analysis}

Test for the screening and identification of chemical bioactive chemical constituent Mormordica charantia (Linn) were carried out with the extract using the standard procedure as described.

\section{Some in-vitrol antioxidant analyses of the plants samples}

\section{Determination of DPPH free radical scavenging ability}

The 1,1- diphenyl-2-picryhydrazyl (DDPH) free radical scavenging ability of the extract was determined using standard method. Briefly, $1.0 \mathrm{~mL}$ of different concentrations $(20,40$ and $80 \mathrm{mg} / \mathrm{mL}$ ) of the extracts was placed in respective test tubes. 1.0 ML of $0.1 \mathrm{Mm}$ methanolic DPPH solution was added to the samples. These samples were vortexed, and incubated in dark at room temperature for 30 minutes before absorbance measured at $516 \mathrm{~cm}$. Decreased absorbance of the sample indicates DDPH free radical scavenging capability. Distilled water was replaced for the extract in the control.

\section{Determination of ferric reducing antioxidant power}

The reducing property of the extract was determined using standard method .This method is based on the reduction of (Fe3+) ferricyanide in stoichiometric excess relative to the antioxidants. Different concentrations of the methanolic extract of the sample and its various fractions $(10-50 \mathrm{~g} / \mathrm{Ml})$ was added to $1.0 \mathrm{~mL}$ of $200 \mathrm{Mm}$ of sodium phosphate buffer $\mathrm{PH} 6.6$ and $1.0 \mathrm{~mL}$ of $1 \%$ potassium ferricyanide $\left[\mathrm{K}_{3} \mathrm{Fe}(\mathrm{CN})_{6}\right]$. The mixture was incubated at $50^{\circ} \mathrm{C}$ for 20 minutes, thereafter $1.0 \mathrm{~mL}$ of freshly prepared $10 \%$ TCA was quickly added and centrifuged at 2000rpm for 10 minutes, $1.0 \mathrm{~mL}$ of the supernatant was mixed with $1.0 \mathrm{~mL}$ of distilled water and $0.25 \mathrm{ml}$ of $0.1 \%$ of $\mathrm{FeCl}_{3}$ solution was added. Distilled water was used for blank without the test sample while control solution contained all other reagents except the $0.1 \%$ potassium ferricyanide. Absorbances of these mixtures were measured at $700 \mathrm{~nm}$ using a spectrophotometer. Decreased absorbance indicates ferric reducing 
power capability of sample. The percentage Ferric reducing antioxidant power (\%) was subsequently calculated $=\left[\left(\mathrm{Abs}_{\text {control }}-\mathrm{Abs}_{\text {sample }}\right) / \mathrm{Abs}_{\text {control }}\right] \times 100$

\section{Determination of Fe2+ Chelation}

The ability of the extract to chelate $\mathrm{Fe}^{2+}$ was determined using standard method. Freshly prepared $500 \mathrm{M} \mathrm{FeSO}_{4}(150 \mathrm{~L})$ was added to a reaction mixture containing $168 \mathrm{~L}$ of $0.1 \mathrm{M}$ Tris- HCL (PH 7.4), $218 \mathrm{~L}$ saline and the different concentrations of extracts $(0-25 \mathrm{~L})$. The reaction

mixture was incubated for 5 minutes before the addition of $13 \mathrm{~L}$ of $0.25 \% 1,10$ phenanthroline $(\mathrm{w} / \mathrm{v})$. The absorbance was subsequently measured at $510 \mathrm{~nm}$ in a spectrophotometer.

The percentage of Fe (II) chelating ability was subsequently calculated with respect to the control (which contains all the reagents without the test sample). The Fe2+ chelation ability $+\left[\left(\mathrm{Abs}_{\text {control }}-\mathrm{Abs}_{\text {sample }} / \mathrm{Abs}_{\text {control }}\right] \times 100\right.$

Determination of Vitamin $\mathrm{C}$ (ascorbic acid) Contents in various fruit and vegetable by UV- spectrophotometry and titration methods

The aim of the work is to determine the amount of Ascorbic acid in the samples

\section{Extraction from plant source}

Mormordica charantia (Linn) was blended, $1 \mathrm{~g}$ of the sample was transferred into a $100 \mathrm{ml}$ volumetric flask. $10 \mathrm{ml}$ of water was added to the sample. $5 \mathrm{ml}$ of Acetic acid was added to the sample using a pipette for homogenization and it was shaken appropriately

The extraction was left for 3 hours. The solution was filtered and a clear solution was obtained.

\section{Estimation}

To the filtered solution,

Few drops of Bromine water was added until the solution became coloured. This is to confirm the complete oxidation of Ascorbic acid to dehydroascorbic acid. Few drops of thiourea solution was added to it to remove excess bromine and thus a clear solution was obtained. Then, 2-4 Dinitrophenyl hydrazine solution was added thoroughly with all standards and also with the oxidized Ascorbic acid and make up to $10 \mathrm{ml}$ mark with Acetic acid. The absorbance of the sample was examined at $520 \mathrm{~nm}$ using UV spectrophotometer to determine the concentration of Ascorbic acid under testing.

\section{Statistical analysis}

All the data are presented as standard error of the mean \pm (SEM) from triplicate experiments and were analysed using Statistically Package for Social Sciences (SPSS) software version 22.0. A one-way analysis of variance (ANOVA) was used for multiple comparison. The correlation between result properties was described by the Pearson product-movement correlation.

\section{RESULTS}

\section{Extract Yield}

After the extraction process, the $70 \%$ ethanol yielded the highest value of the extract The ethanol extracts of Mormordica charantia Linn showed yields of $22.45 \%$ while the yields from water extracts is $18.60 \%$ (Figure 1).

\section{Bacterial load of Ready-to-eat Food Samples Sold in Akure metropolis}

Total bacterial loads of Ready-to-eat Food Samples Sold in Akure metropolis

The total bacterial counts of Ready-to-eat food samples sold in Akure metropolis is shown in Figures 2 to 5 . Moimoi purchased from vendor A had a significantly high bacterial loads with a value of $1.38 \pm 0.012 \times 10^{4} \mathrm{cfu} / \mathrm{g}$ whereas Moimoi from vendor $\mathrm{C}$ had the lowest total bacterial loads $1 \times 10^{3} \pm 0.012 \mathrm{cfu} / \mathrm{g}$. Total bacterial counts of Fried rice from different vendors varied with no significant difference $(\mathrm{P} \leq 0.05)$, sample from vender $\mathrm{A}$ had the highest bacterial loads with value of $2.5 \pm 0.01 \times 10^{3} \mathrm{cfu} / \mathrm{g}$ whereas sample from vendor $\mathrm{E}$ had the lowest bacterial loads with value of $1.2 \times 10^{3} \pm 0.01 \mathrm{cfu} / \mathrm{g}$. Suya Sample purchased from vendor A had the highest bacterial loads $\left(1.33 \pm 0.02 \times 10^{4} \mathrm{cfu} / \mathrm{g}\right)$, whereas sample from vendor $\mathrm{S}$ had the lowest bacterial loads $\left(1.25 \pm 0.02 \times 10^{4} \mathrm{cfu} / \mathrm{g}\right)$. White rice purchased from vendor $\mathrm{C}$ had the highest bacterial loads with value of $2.7 \pm 0.03 \times 10^{3} \mathrm{cfu} / \mathrm{g}$ compare to sample from other vendors.

Among all the samples collected, Moimoi purchased from vendor A had the highest bacterial loads with value of $1.38 \pm 0.02 \times 10^{4} \mathrm{cfu} / \mathrm{g}$, followed by Suya sample purchased from vendor $\mathrm{D}$ whereas white rice purchased from vendor $\mathrm{B}$ had the lowest bacterial loads. The total bacterial load of spoilt food sample is higher than Ready-to-eat food sample. Among the spoilt sample analyzed spoilt Moimoi had the highest bacterial loads with value of $1.29 \pm 0.04 \times 10^{3} \mathrm{cfu} / \mathrm{g}$ (figure 6).

\section{Morphological and Biochemical Characteristics of Bacteria species isolated from Ready-to-eat food sample Sold in Akure metropolis}

The morphological and Biochemical results of bacteria isolate from Ready-to-eat food is shown in Table 1. The percentage of occurrence of different bacterial genera in Ready-to-eat food sample analyzed is shown in figure 4. The bacteria isolated from the samples belong to the genera of Staphylococcus, Citrobacter, Enterobacter, Salmonella, Enterococcus, Klebsiella, Bacillus, Escherichia, Kocuria, Streptococcus, Kluyveria, Shinwellia, Pseudomonas, Serratia, Pectobacterium and Pantoea. Enterobacter had highest frequency of occurrence of $23.1 \%$ among all the bacterial genera isolates from Ready-to-eat food samples, Followed by Staphylococcus and Salmonella with uniform frequency of occurrence of $17.9 \%$.

Distribution of Bacteria species isolated from Ready-to-eat foods sold in Akure metropolis

Distribution of Bacteria species isolated from Ready-to-eat foods sold in Akure metropolis and their spoilt form with their percentage of occurrence in bracket is shown in table 2. Enterobacter (Cronobacter) sakzaki was isolated from almost all types of food samples used whereas Staphylococcus heamolyticus, Klebsiella pnuemoniae, Enteric group 69, Salmonella typhi and Pantoea agglomerans were present in only one type of RTE food samples. Figure 7 showed the percentage of occurrence of different bacterial genera in Ready-to-eat food sold in Akure metropolis.

\section{Antibiotic susceptibility pattern result for pathogenic organism isolated from RTE food sold in Akure metropolis}

The Antibiotic susceptibility pattern for Gram negative and Gram positive bacterial isolated from RTE food sold in Akure metropolis is shown in Table 3 and 4. Kluyveria intermedia resist the effect all the antibiotics used. Gentamycin $(30 \mu \mathrm{g})$ is the most effective antibiotics on Gram negative bacteria isolates whereas Pefloxacin $(30 \mu \mathrm{g})$ had the lowest effect on Gram negative bacteria isolates. Streptomycin $(30 \mu \mathrm{g})$ was effective for all the Gram positive bacteria isolates whereas Ampiclox $(30 \mu \mathrm{g})$ and Pefloxacin $(30 \mu \mathrm{g})$ were effective on one of the gram positive bacteria isolates.

\section{Phytochemical Composition of the Extracts}

Tannin, saponin, phlobatannin, steroids and alkaloid were observed to be present in the water extract of Momordica charantia (Linn) with no traces of flavonoids, cardiac glycosides, anthraquinones and phenols. phlobatannin, steroids, cardiac glycosides alkaloids and phenols where present in ethanolic extracts sample of Momordica charantia (Linn). Table 5 and Table 6 showed the components present.

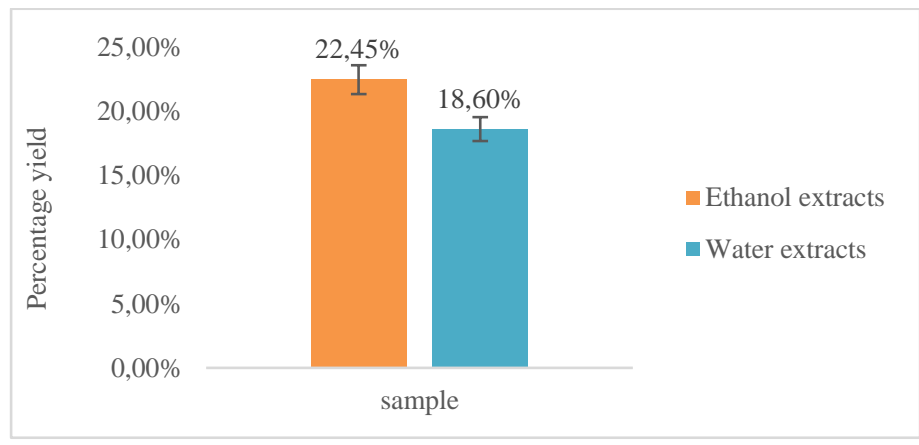

Error bar +/-2 SE

Figure 1 Percentage yields of ethanol and water extracts of $M$. charantia (Linn) per $250 \mathrm{~g}$ 


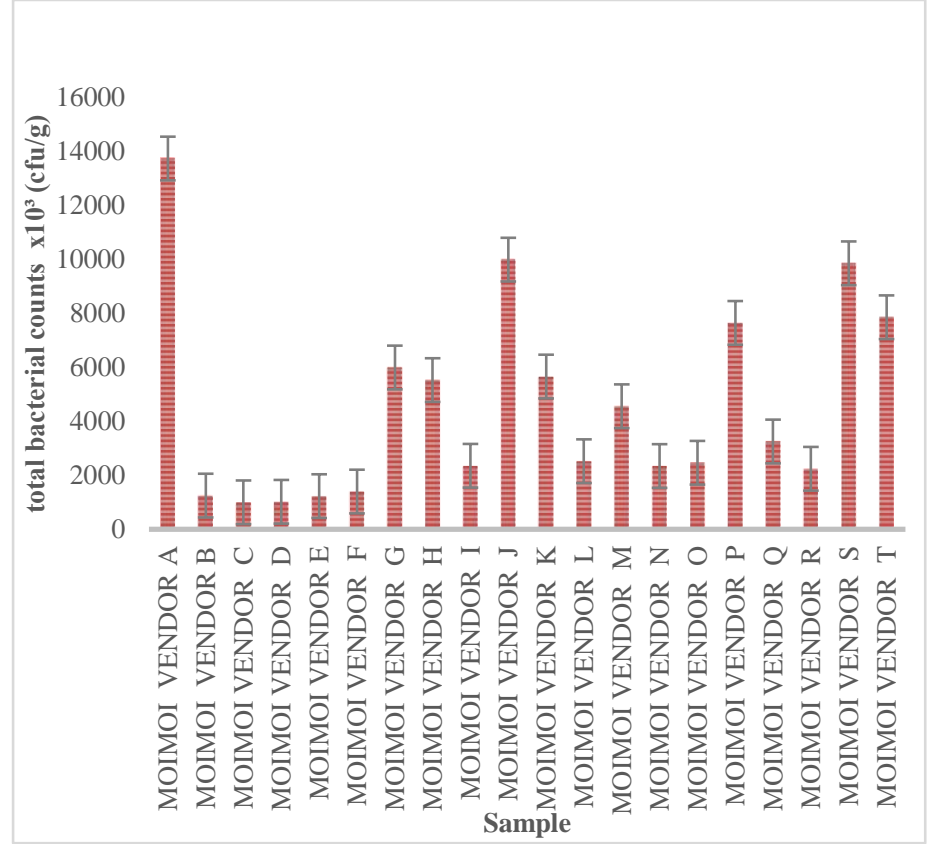

Error bar $+/-2 \mathrm{SE}$

Figure 2 The total bacterial counts of Ready-to-eat Moimoi sold in Akure metropolis

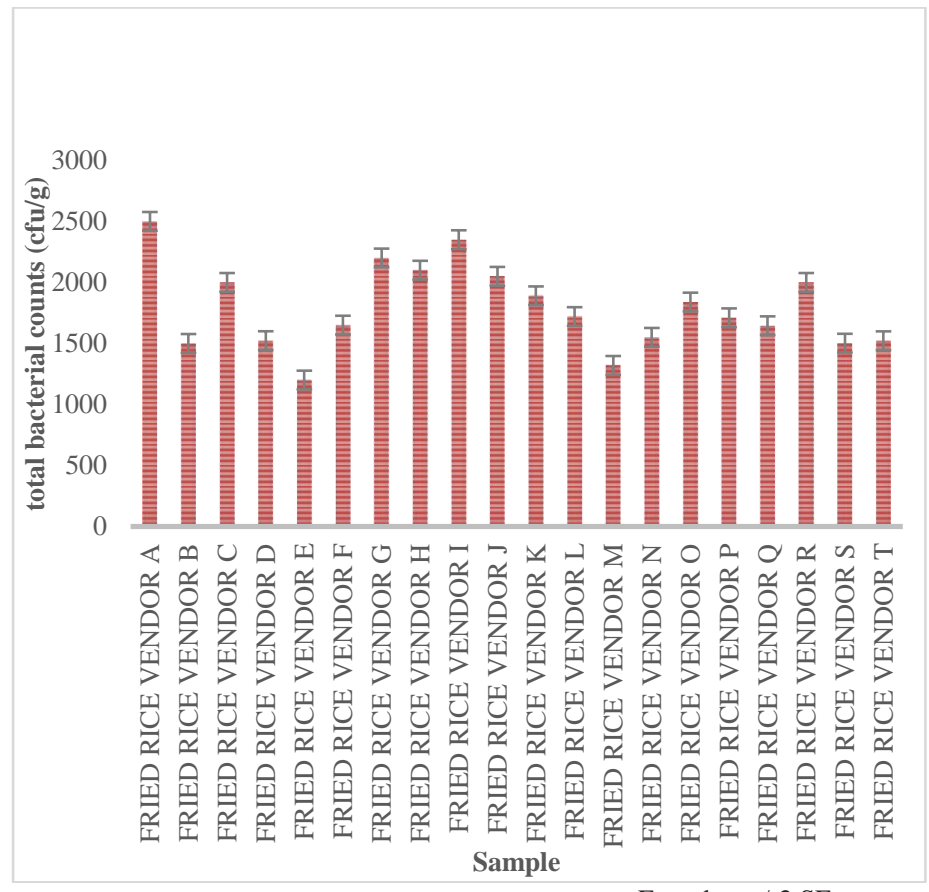

Figure 3 The total bacterial counts of Ready-to-eat Fried rice sold in Akure metropolis

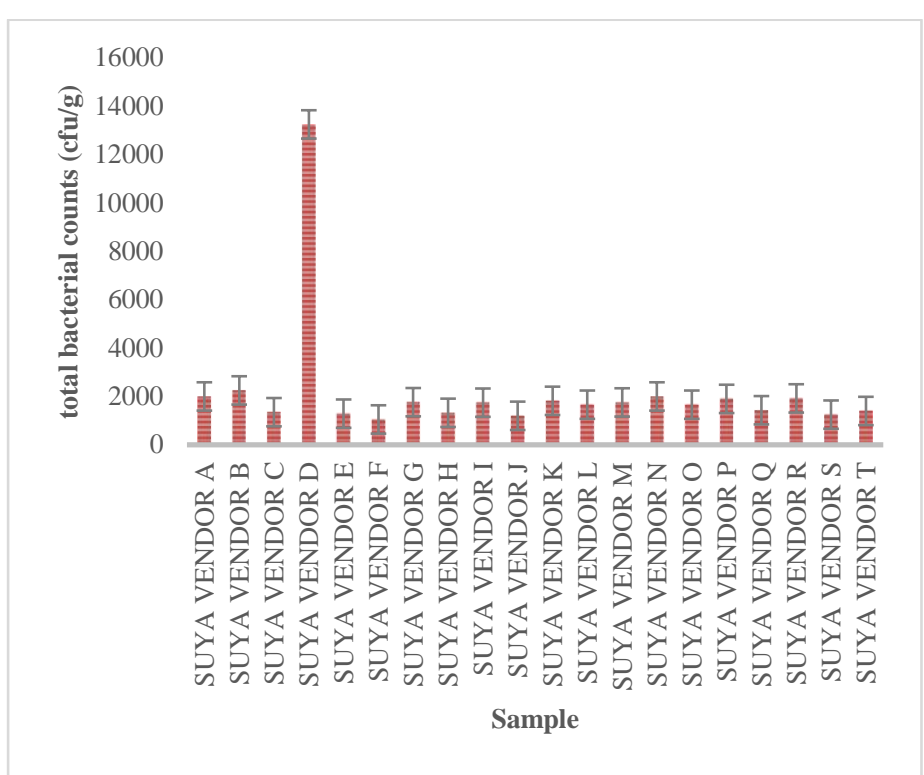

Error bar $+/-2 \mathrm{SE}$

Figure 4 The total bacterial counts of Ready-to-eat Suya sold in Akure metropolis

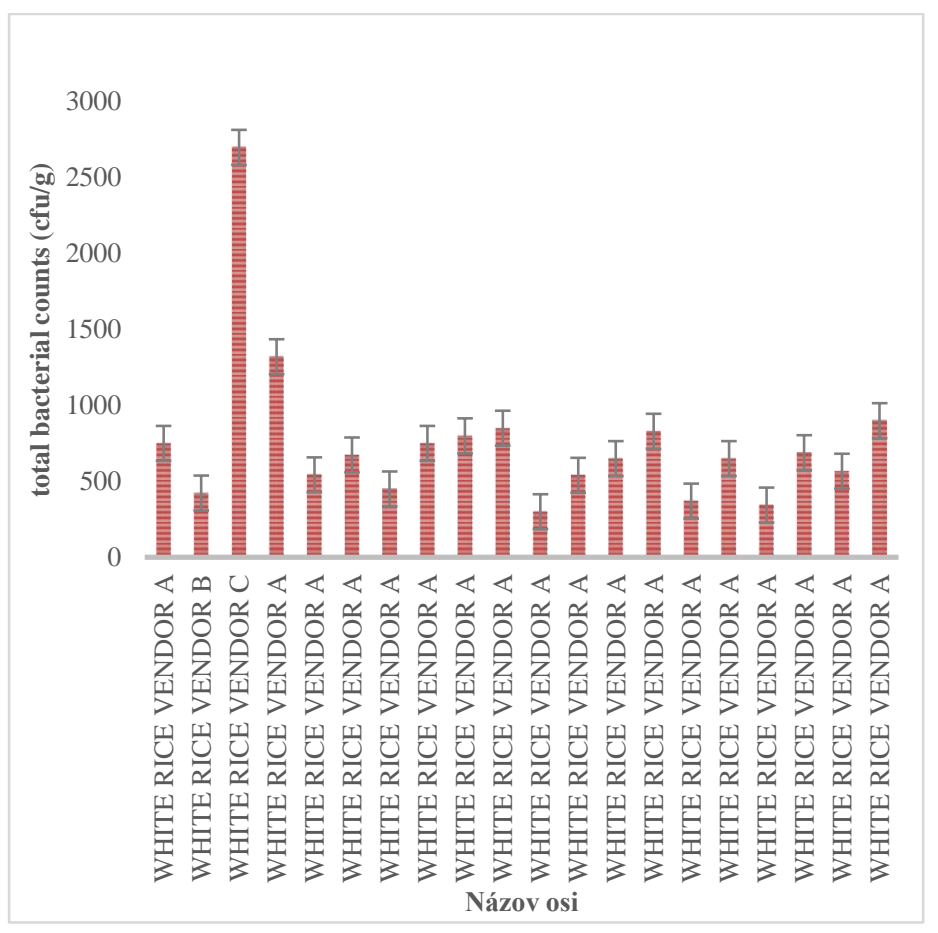

Error bar +/-2 SE

Figure 5 The total bacterial counts of Ready-to-eat White rice sold in Akure metropolis 


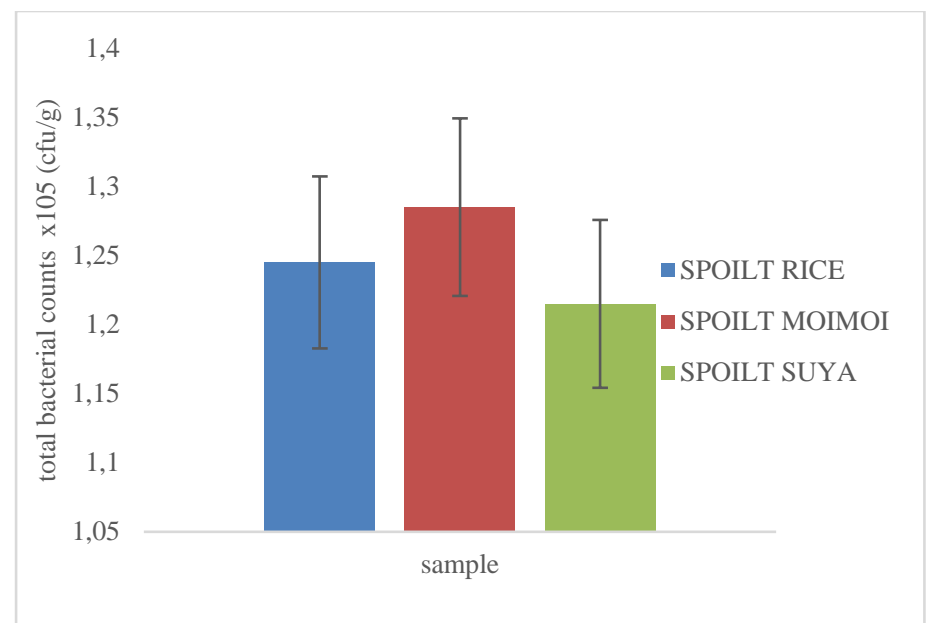

Error bar $+/-2 \mathrm{SE}$

Figure 6 The total bacterial counts of isolates from spoilt form of Ready-to-eat food sold in Akure metropolis

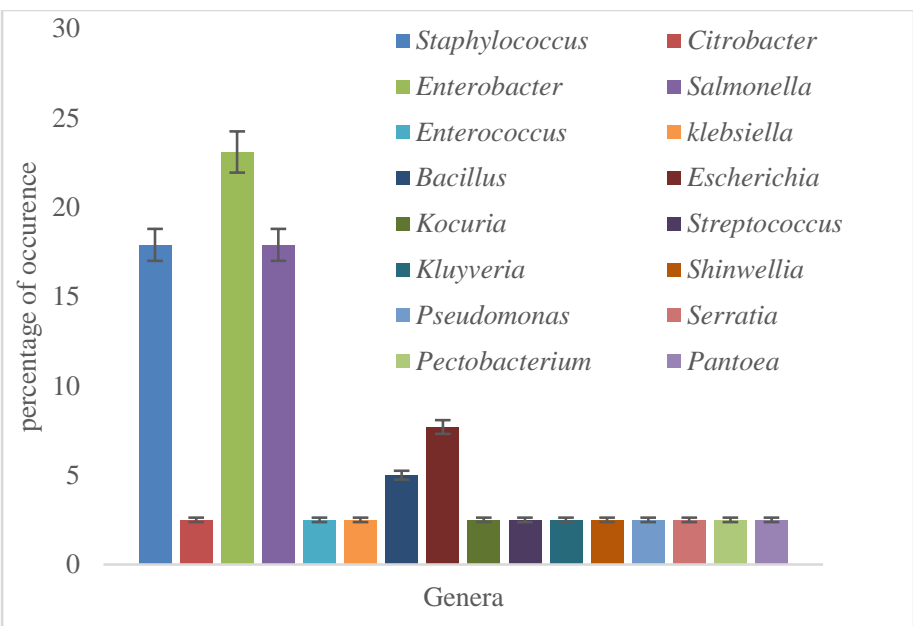

Error bar $+/-2$ SE

Figure 7 Percentage of occurrence of different bacterial genera in Ready-to-eat food sold in Akure metropolis.

Table 1 Result of morphological and biochemical results of bacteria isolates from Ready-to-eat food sold in Akure metropolis.

\section{Biochemical tests}

Tsia

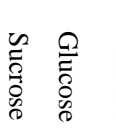

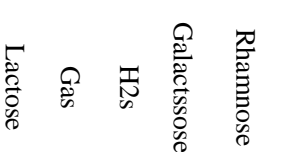

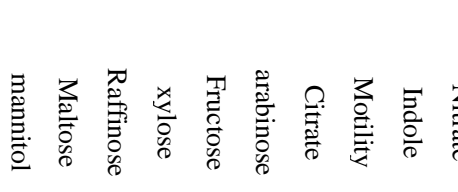

Gram reaction

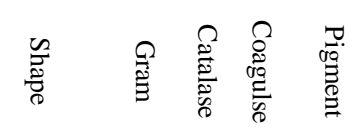

Suspected bacteria

\begin{tabular}{|c|c|c|c|c|c|c|c|c|c|c|c|c|c|c|c|c|c|c|c|c|c|c|c|c|c|}
\hline+ & + & + & + & + & + & + & + & + & + & + & + & + & + & + & - & + & + & - & $\mathrm{Nd}$ & Rod & - & + & - & + & Citrobacter freundii \\
\hline+ & + & + & + & - & + & + & + & + & + & + & + & + & + & + & - & + & + & + & $\mathrm{Nd}$ & $\operatorname{rod}$ & - & + & - & & Enterobacter sakzakii \\
\hline - & + & - & + & + & + & + & + & + & - & + & + & + & + & + & - & + & + & - & + & $\operatorname{rod}$ & - & + & - & + & Salmonella enterica subsp enterica \\
\hline- & + & - & - & - & + & + & + & + & + & + & + & + & + & + & - & + & + & + & + & cocci & + & + & - & + & Enterococcus casseliflavus \\
\hline- & + & + & + & - & + & + & + & + & + & + & - & + & + & + & - & + & + & + & $\mathrm{Nd}$ & $\operatorname{rod}$ & - & + & - & + & Enterobacter nimipressuralis \\
\hline+ & + & + & + & - & + & + & + & + & + & + & + & + & + & - & - & + & - & + & $\mathrm{Nd}$ & rod & - & + & - & + & klebsiella pпиетопiae \\
\hline+ & + & + & + & - & + & + & + & + & + & + & + & + & + & + & - & + & - & + & $\mathrm{Nd}$ & $\operatorname{rod}$ & - & + & - & + & Cronobacter sakazakii \\
\hline- & + & - & - & + & - & - & - & + & + & + & + & - & + & + & - & + & - & + & + & rod & + & + & - & + & Bacillus cereus \\
\hline- & + & + & + & - & + & + & + & + & - & + & - & + & - & + & + & + & + & - & $\mathrm{Nd}$ & $\operatorname{rod}$ & - & + & - & + & Escherichia coli \\
\hline- & + & - & - & - & - & - & + & + & + & + & + & + & + & + & - & + & - & - & + & cocci & + & + & - & + & Kocuria varians \\
\hline+ & + & + & - & - & + & - & + & + & - & - & - & - & + & - & - & + & + & + & - & cocci & + & + & + & + & Staphylococcus aureus \\
\hline+ & + & + & - & - & + & - & - & + & + & + & + & + & + & + & - & + & + & + & + & cocci & + & + & - & + & Streptococcus salivarius subp:t \\
\hline+ & + & + & + & - & + & + & + & + & + & + & + & + & - & + & - & + & + & + & $\mathrm{Nd}$ & $\operatorname{rod}$ & - & + & - & $\mathrm{Nd}$ & Kluyveria intermedia \\
\hline+ & + & + & + & - & + & + & + & + & + & + & + & + & + & + & - & + & + & - & $\mathrm{Nd}$ & cocci & + & + & - & $\mathrm{Nd}$ & Staphylococcus gallinarum \\
\hline- & + & - & - & - & - & - & - & - & - & - & - & - & - & - & - & + & - & - & + & $\operatorname{rod}$ & - & + & - & + & Shinwellia pseudoproteus \\
\hline- & - & - & + & - & - & - & + & - & - & - & - & - & + & + & - & + & - & - & - & $\operatorname{rod}$ & - & + & - & + & Pseudomonas aeruginosa \\
\hline+ & + & - & + & - & + & - & + & + & + & + & + & + & + & + & - & + & + & + & + & rod & - & + & - & + & Serratia liquefaciens \\
\hline- & + & - & + & + & + & + & + & + & + & + & + & + & + & + & - & + & + & + & + & $\operatorname{rod}$ & - & + & - & + & Enteric group 69 \\
\hline- & + & - & + & - & + & - & + & + & + & + & + & + & - & + & - & + & + & + & - & $\operatorname{rod}$ & - & + & - & + & Escherichia vulneris \\
\hline+ & + & + & + & + & + & + & + & + & + & - & + & + & + & + & - & + & + & + & $\mathrm{Nd}$ & rod & - & + & - & + & Pectobacterium carotovorum \\
\hline- & + & + & + & + & + & + & + & + & - & + & + & + & + & + & - & + & + & - & $\mathrm{Nd}$ & $\operatorname{rod}$ & - & + & - & + & Salmonella typhi \\
\hline+ & + & + & + & + & + & + & + & + & + & + & + & + & + & + & - & + & + & + & + & rod & - & + & - & $\mathrm{Nd}$ & Pectobacterium carotovorum \\
\hline- & + & - & - & - & + & + & + & + & + & + & + & + & + & + & - & $\begin{array}{l}\mathrm{N} \\
\mathrm{d}\end{array}$ & + & + & $\mathrm{Nd}$ & $\operatorname{rod}$ & - & + & - & + & Pantoea agglomerans \\
\hline
\end{tabular}

KEY: Nd: not define. 
Table 2 Percentage of occurrence of bacteria species isolated from Ready-to-eat foods sold in Akure metropolis

\begin{tabular}{|c|c|c|c|c|c|c|c|}
\hline Bacterial isolates & Ready to & eat food & Sample & & Spoilt food & Sample & \\
\hline & $\begin{array}{l}\text { Moimoi } \\
\text { N1=20 }\end{array}$ & $\begin{array}{l}\text { Fried Rice } \\
\quad \mathrm{N} 2=20\end{array}$ & $\begin{array}{c}\text { Suya } \\
\text { N3=20 }\end{array}$ & $\begin{array}{l}\text { White rice } \\
\text { N4 }=20\end{array}$ & $\begin{array}{c}\text { Spoilt rice } \\
\mathrm{N} 5=1\end{array}$ & $\begin{array}{l}\text { Spoilt Moimoi } \\
\text { N6 }=1\end{array}$ & $\begin{array}{l}\text { Spoilt } \\
\text { Suya } \\
\text { N6=1 }\end{array}$ \\
\hline Staphylococcus gallinarum & $66 \%$ & - & - & $33 \%$ & $100 \%$ & - & \\
\hline Citrobacter freundii & - & - & - & - & - & $100 \%$ & $100 \%$ \\
\hline Enterobacter (Cronobacter) sakzaki & $33 \%$ & $50 \%$ & $25 \%$ & - & $100 \%$ & $100 \%$ & $100 \%$ \\
\hline Salmonella enterica subsp enterica & $33 \%$ & - & & $66 \%$ & - & $100 \%$ & \\
\hline Enterococcus casseliflavus & - & - & $25 \%$ & - & - & - & \\
\hline Enterobacter nimipressuralis & - & - & $50 \%$ & & $100 \%$ & & \\
\hline Staphylococcus heamolyticus & $33 \%$ & - & - & - & - & - & \\
\hline Klebsiella pпиетопiae & - & $50 \%$ & - & - & - & - & \\
\hline Bacillus cereus & - & - & $25 \%$ & $33 \%$ & - & - & $100 \%$ \\
\hline Escherichia coli & $33 \%$ & - & $25 \%$ & - & - & - & \\
\hline Kocuria varians & - & $50 \%$ & - & - & - & - & \\
\hline Staphylococcus aureus & - & - & $20 \%$ & - & $100 \%$ & - & $100 \%$ \\
\hline $\begin{array}{l}\text { Streptococcus salivarius subsp: } \\
\text { thermophilus }\end{array}$ & - & - & - & - & $100 \%$ & - & \\
\hline Kluyveria intermedia & - & - & - & $33 \%$ & - & - & \\
\hline Escherichia vulneris & $33 \%$ & - & - & - & - & $100 \%$ & $100 \%$ \\
\hline Shinwellia pseudoproteus & - & $50 \%$ & - & - & - & - & \\
\hline Pseudomonas aeruginosa & - & - & - & - & - & $100 \%$ & $100 \%$ \\
\hline Serratia liquefaciens & - & - & $25 \%$ & - & - & - & \\
\hline Enteric group 69 & $33 \%$ & - & - & - & - & - & \\
\hline Pectobacterium carotovorum & - & - & - & - & - & $100 \%$ & \\
\hline Salmonella typhi & - & - & $50 \%$ & - & - & - & \\
\hline Pantoea agglomerans & - & - & - & - & $100 \%$ & - & \\
\hline
\end{tabular}

KEY: ND- Not detected, N1... N7= Number of vendor for food sample collected

Table 3 Antibiotic susceptibility pattern result of Gram negative bacterial isolates from RTE food sold in Akure metropolis

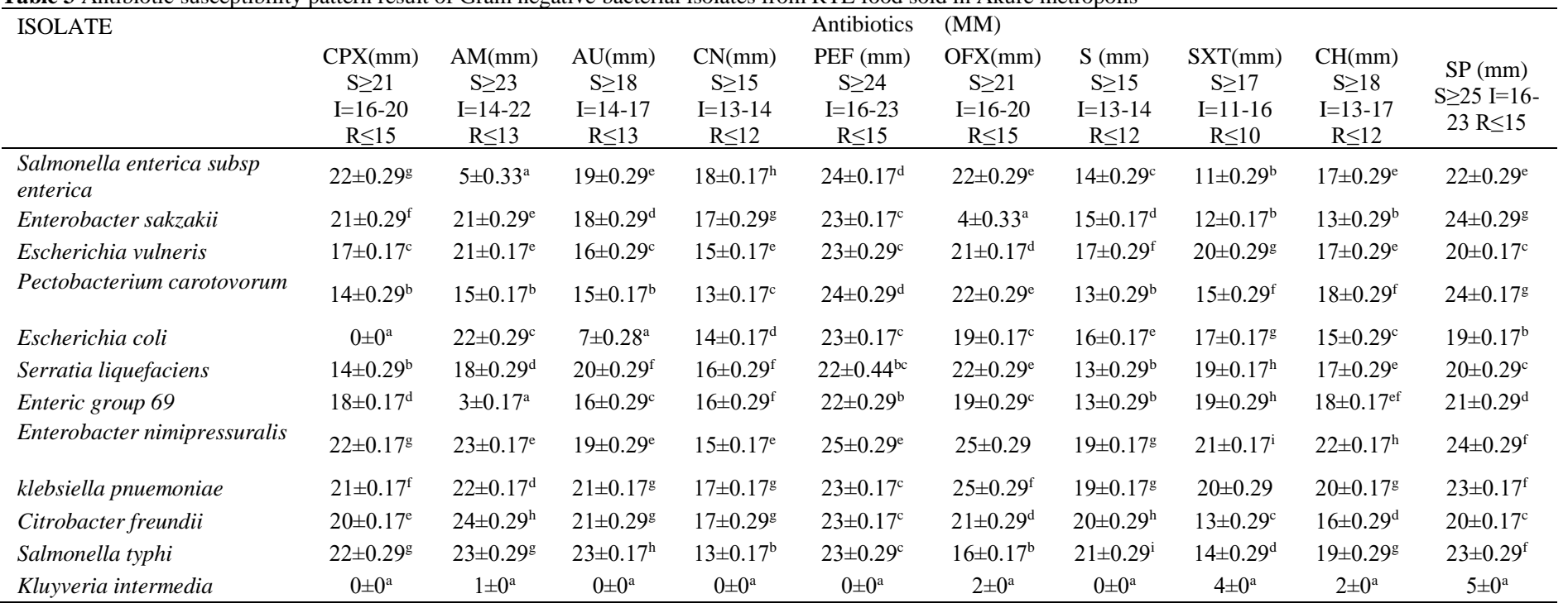

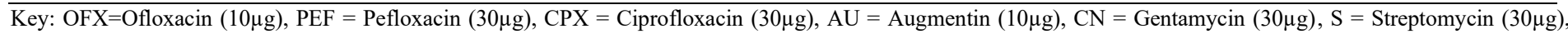
$\mathrm{SXT}=$ Septrin $(30 \mu \mathrm{g}), \mathrm{AM}=$ Amoxicillin $(30 \mu \mathrm{g}), \mathrm{CH}=\mathrm{Chloramphenicol}(30 \mu \mathrm{g}), \mathrm{SP}=$ Sparfloxacin $(30 \mu \mathrm{g}) . \mathrm{R}=$ resistant, I=intermediate and $\mathrm{S}=$ susceptible according to the Clinical and Laboratory Standards Institute (CLSI, 2018). Values are expressed in mean \pm SEM. $P<0.05$ was considered to be statistically significant. 
Table 4 Antibiotic susceptibility pattern of Gram positive bacterial isolates from RTE food sold in Akure metropolis ISOLATE

\begin{tabular}{|c|c|c|c|c|c|c|c|c|c|c|}
\hline D. & $\begin{array}{c}\mathrm{AM}(\mathrm{mm}) \\
\mathrm{S} \geq 18 \\
\mathrm{I}=14-17 \\
\mathrm{R} \leq 13\end{array}$ & $\begin{array}{c}\mathrm{Z}(\mathrm{mm}) \\
\mathrm{S} \geq 18 \\
\mathrm{I}=15-17 \\
\mathrm{R} \leq 14\end{array}$ & $\begin{array}{c}\mathrm{APX}(\mathrm{mm}) \\
\mathrm{S} \geq 23 \\
\mathrm{I}=14-23 \\
\mathrm{R} \leq 13\end{array}$ & $\begin{array}{c}\mathrm{CN}(\mathrm{mm}) \\
\mathrm{S} \geq 15 \\
\mathrm{I}=13-14 \\
\mathrm{R} \leq 12\end{array}$ & $\begin{array}{c}\mathrm{PEF}(\mathrm{mm}) \\
\mathrm{S} \geq 24 \\
\mathrm{I}=16-23 \\
\mathrm{R} \leq 15\end{array}$ & $\begin{array}{c}\mathrm{E}(\mathrm{mm}) \\
\mathrm{S} \geq 23 \\
\mathrm{I}=14-22 \\
\mathrm{R} \leq 13\end{array}$ & $\begin{array}{c}\mathrm{S}(\mathrm{mm}) \\
\mathrm{S} \geq 15 \\
\mathrm{I}=13-14 \\
\mathrm{R} \leq 12\end{array}$ & $\begin{array}{c}\mathrm{SXT}(\mathrm{mm}) \\
\mathrm{S} \geq 17 \\
\mathrm{I}=11-16 \\
\mathrm{R} \leq 10\end{array}$ & $\begin{array}{c}\mathrm{CPX}(\mathrm{mm}) \\
\mathrm{S} \geq 21 \\
\mathrm{I}=16-20 \\
\mathrm{R} \leq 15\end{array}$ & $\begin{array}{c}\mathrm{R}(\mathrm{mm}) \\
\mathrm{S} \geq 20 \\
\mathrm{I}=13-19 \\
\mathrm{R} \leq 12\end{array}$ \\
\hline Enterococcus casseliflavus & $19 \pm 0.17^{\mathrm{d}}$ & $19 \pm 0.29^{\mathrm{b}}$ & $21 \pm 0.17^{\mathrm{d}}$ & $16 \pm 0.17^{\mathrm{d}}$ & $21 \pm 0.17^{\mathrm{c}}$ & $24 \pm 0.29^{\mathrm{d}}$ & $17 \pm 0.29^{\mathrm{a}}$ & $19 \pm 0.29^{\mathrm{d}}$ & $22 \pm 0.29^{\mathrm{c}}$ & $22 \pm 0.29^{\mathrm{d}}$ \\
\hline Staphylococcus heamolyticus & $17 \pm 0.29^{\mathrm{b}}$ & $17 \pm 0.29^{\mathrm{a}}$ & $15 \pm 0.29^{\mathrm{b}}$ & $14 \pm 0.29^{\mathrm{b}}$ & $24 \pm 0.17^{\mathrm{e}}$ & $18 \pm 0.29^{b}$ & $17 \pm 0.29^{\mathrm{a}}$ & $20 \pm 0.29^{\mathrm{e}}$ & $24 \pm 0.29^{\mathrm{d}}$ & $15 \pm 0.17^{\mathrm{a}}$ \\
\hline varians & $17 \pm 0.17^{\mathrm{b}}$ & $21 \pm 0.17^{\mathrm{d}}$ & $23 \pm 0.17^{\mathrm{e}}$ & $15 \pm 0.17^{\mathrm{c}}$ & $0 \pm 0^{\mathrm{a}}$ & $16 \pm 0.17^{\mathrm{a}}$ & $19 \pm 0.17^{\mathrm{b}}$ & $13 \pm 0.17^{\mathrm{b}}$ & $22 \pm 0.17^{\mathrm{bc}}$ & $16 \pm 0.17^{\mathrm{b}}$ \\
\hline $\begin{array}{l}\text { Bacillus cereus } \\
\text { Staphylococcus aureus }\end{array}$ & $\begin{array}{l}0 \pm 0^{\mathrm{a}} \\
0 \pm 0^{\mathrm{a}}\end{array}$ & $\begin{array}{l}20 \pm 0.29^{\mathrm{c}} \\
22 \pm 0.17^{\mathrm{e}}\end{array}$ & $\begin{array}{c}0 \pm 0^{\mathrm{a}} \\
19 \pm 0.29^{\mathrm{c}}\end{array}$ & $\begin{array}{l}16 \pm 0.29^{\mathrm{d}} \\
13 \pm 0.29^{\mathrm{a}}\end{array}$ & $\begin{array}{l}17 \pm 0.29^{\mathrm{b}} \\
23 \pm 0.29^{\mathrm{d}}\end{array}$ & $\begin{array}{l}15 \pm 0.29^{\mathrm{a}} \\
23 \pm 0.29^{\mathrm{c}}\end{array}$ & $\begin{array}{l}17 \pm 0.29^{\mathrm{a}} \\
17 \pm 0.29^{\mathrm{a}}\end{array}$ & $\begin{array}{c}0 \pm 0^{\mathrm{a}} \\
18 \pm 0.17^{\mathrm{c}}\end{array}$ & $\begin{array}{l}19 \pm 0.29^{\mathrm{a}} \\
21 \pm 0.29^{\mathrm{b}}\end{array}$ & $\begin{array}{l}20 \pm 0.29^{\mathrm{c}} \\
22 \pm 0.29^{\mathrm{e}}\end{array}$ \\
\hline
\end{tabular}

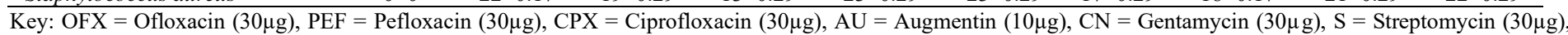

$\mathrm{SXT}=$ Septrin $(30 \mu \mathrm{g}), \mathrm{AM}=$ Amoxicillin $(30 \mu \mathrm{g}), \mathrm{Z}=$ zinnacel $(30 \mu \mathrm{g}), \quad \mathrm{APX}=$ Ampiclox $(30 \mu \mathrm{g}) . \mathrm{R}=$ resistant. I=intermediate, $\mathrm{S}=$ susceptible according to the Clinical and Laboratory Standards Institute (CLSI, 2018). Values are expressed in mean \pm SEM. $P<0.05$ was considered to be statistically significant.

Table 5 Qualitative phytochemical composition of Ethanol and aqueous Extracts of Mormordica charantia Linn

\begin{tabular}{lcc}
\hline Bioactive compound & Ethanol & WATER \\
\hline Saponins & + & - \\
Tannins & + & - \\
Phlobatannins & + & + \\
Flavonoids & - & - \\
Steroids & + & - \\
Terpenoids & - & + \\
Cardiac glycosides & - & + \\
Alkaloids & + & + \\
Anthraquinones & - & - \\
Phenols & - & + \\
\hline
\end{tabular}

Key: + = Detected, - = Not detected

Table 6 Quantitative phytochemical composition of Ethanol and aqueous Extracts of Mormordica charantia Linn

\begin{tabular}{lcc}
\hline Bioactive compound & Ethanol & WATER \\
\hline Saponins & $6.787 \pm 0.0075^{\mathrm{d}}$ & $2.291 \pm 0.054^{\mathrm{a}}$ \\
Tannins & $5.775 \pm 0.0110^{\mathrm{c}}$ & $2.834 \pm 0.0100^{\mathrm{b}}$ \\
Phlobatannins & $3.109 \pm 0.0040^{\mathrm{a}}$ & $4.732 \pm 0.011^{\mathrm{de}}$ \\
Flavonoids & - & - \\
Steroids & $7.088 \pm 0.0130^{\mathrm{e}}$ & \\
Terpenoids & - & $4.899 \pm 0.00145^{\mathrm{e}}$ \\
Cardiac glycosides & & $4.583 \pm 0.016^{\mathrm{d}}$ \\
Alkaloids & $3.873 \pm 0.006^{\mathrm{ab}}$ & $3.393 \pm 0.0055^{\mathrm{c}}$ \\
Anthraquinones & - & - \\
Phenols & - & $9.131 \pm 0.012^{\mathrm{f}}$ \\
\hline
\end{tabular}

Values are expressed in mean \pm SEM. $P<0.05$ was considered to be statistically significant.

Antibacterial Activity of ethanolic and water extracts on bacterial isolates from RTE foods sold in Akure metropolis

The Zone of inhibition (mm) of Momordica charantia (Linn) extracts against bacterial isolates from RTE foods sold in Akure metropolis is shown in Tables 7 and 8 . The results from the agar well-diffusion method revealed that the ethanol and water extracts showed significant to moderate antibacterial activity toward all tested isolates except; Escherichia vulneris and Kluyveria intermedia resist the effect of water extracts. Only Kluyveria intermedia resist the effect of ethanol extracts. The highest inhibitory activity of the water extracts was observed for Bacillus cereus with wide inhibition zone diameters $28 \pm 0.29^{1}(\mathrm{~mm})$, followed by Staphylococcus aureus $24 \pm 0.29^{\mathrm{k}}(\mathrm{mm})$ whereas Escherichia vulneris $25 \pm 0.29^{\mathrm{l}}$ $(\mathrm{mm})$ Staphylococcus heamolyticus $24 \pm 0.29^{\mathrm{k}}(\mathrm{mm})$, and Staphylococcus aureus $24 \pm 0.29^{\mathrm{k}}(\mathrm{mm})$ had the highest inhibitory activity for ethanol extracts

Minimum inhibitory concentration (MIC) and Minimum Bactericidal Concentrations (MBC) of Ethanolic and Water Extracts on bacterial isolates from RTE foods sold in Akure metropolis

Minimum inhibitory concentration (MIC) and Minimum Bactericidal Concentrations (MBC) of Ethanolic and Water Extracts on bacterial isolates from RTE foods sold in Akure metropolis is shsown in Table 9. The MIC and MBC values indicated that Momordica charantia Linn specie extracts inhibited the growth of pathogenic bacterial from on bacterial isolates from RTE foods sold in Akure metropolis is shown in Table 9. The minimum inhibitory concentrations (MICs) of the extracts for the test bacteria were relatively lower in water extract compared to the ethanolic extract The concentration ranges from $25 \mathrm{mg} / \mathrm{ml}$ to $100 \mathrm{mg} / \mathrm{ml}$.

Table 7 Zone of inhibition ( $\mathrm{mm}$ ) of water extracts of Mormordica charantia Linn on bacterial isolates from RTE foods sold in Akure metropolis

\begin{tabular}{|c|c|c|c|c|}
\hline \multirow{3}{*}{ ISOLATE } & \multicolumn{4}{|c|}{ ZONE OF INHIBITION (mm) } \\
\hline & & WATER E $>$ & TRACTS & \\
\hline & $\begin{array}{c}200 \mathrm{mg} / \mathrm{ml} \\
(\mathrm{mm})\end{array}$ & $\begin{array}{c}100 \mathrm{mg} / \mathrm{ml} \\
(\mathrm{mm})\end{array}$ & $\begin{array}{c}50 \mathrm{mg} / \mathrm{ml} \\
(\mathrm{mm})\end{array}$ & $\begin{array}{c}25 \mathrm{mg} / \mathrm{ml} \\
(\mathrm{mm})\end{array}$ \\
\hline $\begin{array}{l}\text { Salmonella enterica } \\
\text { subsp enterica }\end{array}$ & $20 \pm 0.29^{\mathrm{i}}$ & $18 \pm 0.17^{\mathrm{i}}$ & $12 \pm 0.29^{\mathrm{d}}$ & $0 \pm 0^{\mathrm{a}}$ \\
\hline $\begin{array}{l}\text { Enterobacter } \\
\text { sakzakii }\end{array}$ & $16 \pm 0.29^{\mathrm{f}}$ & $14 \pm 0.29^{\mathrm{f}}$ & $12.5 \pm 0.29^{\mathrm{d}}$ & $11 \pm 0.17^{\mathrm{c}}$ \\
\hline Escherichia vulneris & $10 \pm 0.17^{b}$ & $7 \pm 0.29^{\mathrm{b}}$ & $0 \pm 0^{\mathrm{a}}$ & $0 \pm 0^{\mathrm{a}}$ \\
\hline $\begin{array}{l}\text { Pectobacterium } \\
\text { carotovorum }\end{array}$ & $18 \pm 0.29^{\mathrm{h}}$ & $16.5 \pm 0.33^{\mathrm{gh}}$ & $15 \pm 0.29^{f}$ & $13 \pm 0.17^{\mathrm{e}}$ \\
\hline Escherichia coli & $17 \pm 0.29^{\mathrm{g}}$ & $16 \pm 0.29^{\mathrm{g}}$ & $13.5 \pm 0.17^{\mathrm{e}}$ & $12 \pm 0.29^{\mathrm{d}}$ \\
\hline Serratia liquefaciens & $13 \pm 0.29^{\mathrm{c}}$ & $11 \pm 0.29^{\mathrm{c}}$ & $0 \pm 0^{\mathrm{a}}$ & $0 \pm 0^{\mathrm{a}}$ \\
\hline Enteric group 69 & $16 \pm 0.17^{\mathrm{f}}$ & $12 \pm 0.29^{\mathrm{d}}$ & $10 \pm 0.29 \mathrm{~b}$ & $0 \pm 0^{\mathrm{a}}$ \\
\hline $\begin{array}{l}\text { Enterobacter } \\
\text { nimipressuralis }\end{array}$ & $22 \pm 0.17^{\mathrm{j}}$ & $17 \pm 0.29^{\mathrm{h}}$ & $14 \pm 0.29^{\mathrm{e}}$ & $11 \pm 0.29^{c}$ \\
\hline $\begin{array}{l}\text { klebsiella } \\
\text { pnuemoniae }\end{array}$ & $20 \pm 0.29^{\mathrm{i}}$ & $18 \pm 0.17^{\mathrm{i}}$ & $16 \pm 0.17^{\mathrm{g}}$ & $14 \pm 0.17^{\mathrm{f}}$ \\
\hline Citrobacter freundii & $15 \pm 0.17^{\mathrm{e}}$ & $13 \pm 0.17^{\mathrm{e}}$ & $12 \pm 0.29^{\mathrm{d}}$ & $7 \pm 0.29^{b}$ \\
\hline Salmonella typhi & $17 \pm 0.29^{\mathrm{g}}$ & $14 \pm 0.29^{\mathrm{f}}$ & $12 \pm 0.17^{\mathrm{d}}$ & $0 \pm 0^{\mathrm{a}}$ \\
\hline $\begin{array}{l}\text { Kluyveria } \\
\text { intermedia }\end{array}$ & $0 \pm 0^{\text {a }}$ & $0 \pm 0^{\mathrm{a}}$ & $0 \pm 0^{\mathrm{a}}$ & $0 \pm 0^{\mathrm{a}}$ \\
\hline $\begin{array}{l}\text { Enterococcus } \\
\text { casseliflavus }\end{array}$ & $14 \pm 0.17^{\mathrm{d}}$ & $13 \pm 0.29^{\mathrm{e}}$ & $11 \pm 0.17^{\mathrm{c}}$ & $7 \pm 0.29^{\mathrm{b}}$ \\
\hline $\begin{array}{l}\text { Staphylococcus } \\
\text { heamolyticus }\end{array}$ & $23 \pm 0.17^{\mathrm{j}}$ & $17 \pm 0.29^{\mathrm{h}}$ & $14 \pm 0.29^{\mathrm{e}}$ & $12 \pm 0.17^{\mathrm{e}}$ \\
\hline Kocuria varians & $18 \pm 0.29^{\mathrm{h}}$ & $16.5 \pm 0.33^{\mathrm{gh}}$ & $14 \pm 0.29^{3}$ & $\begin{array}{l}12.5 \pm 0.3 \\
3^{\mathrm{d}}\end{array}$ \\
\hline Bacillus cereus & $28 \pm 0.29^{1}$ & $20 \pm 0.29^{j}$ & $15 \pm 0.29^{\mathrm{f}}$ & $14 \pm 0.17^{\mathrm{f}}$ \\
\hline $\begin{array}{l}\text { Staphylococcus } \\
\text { aureus }\end{array}$ & $24 \pm 0.29^{\mathrm{k}}$ & $18 \pm 0.29^{\mathrm{i}}$ & $16 \pm 0.29^{\mathrm{g}}$ & $13 \pm 0.29^{\mathrm{e}}$ \\
\hline $\begin{array}{l}\text { Pseudomonas } \\
\text { aeruginosa }\end{array}$ & $17 \pm 0.17^{g}$ & $14 \pm 0.17^{\mathrm{f}}$ & $11 \pm 0.17^{\mathrm{c}}$ & $7 \pm 0.17^{\mathrm{b}}$ \\
\hline
\end{tabular}

Key: 0-10= resistant, $11-13=$ intermediate, $\geq 14=$ susceptible Values are expressed in mean \pm SEM. $P<0.05$ was considered to be statistically significant. 
Table 8 Zone of inhibition (mm) of ethanolic extracts of Mormordica charantia Linn on bacterial isolates isolates from RTE foods sold in Akure metropolis ISOLATE

ZONE OF INHIBITION

ETHANOL EXTRACTS

\begin{tabular}{|c|c|c|c|c|}
\hline & $\begin{array}{c}200 \mathrm{mg} / \mathrm{ml} \\
(\mathrm{mm})\end{array}$ & $\begin{array}{c}100 \mathrm{mg} / \mathrm{ml} \\
(\mathrm{mm})\end{array}$ & $\begin{array}{c}50 \mathrm{mg} / \mathrm{ml} \\
(\mathrm{mm})\end{array}$ & $\begin{array}{c}25 \mathrm{mg} / \mathrm{ml} \\
(\mathrm{mm})\end{array}$ \\
\hline Salmonella enterica subsp enterica & $21 \pm 0.29^{\mathrm{fi}}$ & $15 \pm 0.29^{\mathrm{f}}$ & $11 \pm 0.29^{c}$ & $7 \pm 0.29^{\mathrm{b}}$ \\
\hline Enterobacter sakzakii & $23 \pm 0.29^{j}$ & $19 \pm 0.29$ & $13 \pm 0.29^{\mathrm{e}}$ & $7 \pm 0.29^{\mathrm{b}}$ \\
\hline Pectobacterium carotovorum & $17.5 \pm 0.17^{\mathrm{e}}$ & $16 \pm 0.29^{\mathrm{g}}$ & $14.5 \pm 0.33^{\mathrm{i}}$ & $12 \pm 0.29^{\mathrm{e}}$ \\
\hline Escherichia coli & $17 \pm 0.29^{\mathrm{e}}$ & $14.5 \pm 0.33^{\mathrm{de}}$ & $13 \pm 0.29^{\mathrm{e}}$ & $7 \pm 0.29^{\mathrm{b}}$ \\
\hline Serratia liquefaciens & $22.5 \pm 0.33$ & $18 \pm 0.28^{\mathrm{h}}$ & $15.5 \pm 0.33^{\mathrm{g}}$ & $8.5 \pm 0.17^{\mathrm{c}}$ \\
\hline klebsiella pпиетопiae & $22.5 \pm 0.17^{\mathrm{j}}$ & $19 \pm 0.29^{\mathrm{i}}$ & $17 \pm 0.29^{\mathrm{h}}$ & $15 \pm 0.29^{\mathrm{h}}$ \\
\hline Citrobacter freundii & $17.5 \pm 0.29^{\mathrm{e}}$ & $15 \pm 0.17^{\mathrm{ef}}$ & $12 \pm 0.29^{d}$ & $0 \pm 0^{\mathrm{a}}$ \\
\hline Salmonella typhi & $21 \pm 0.1^{\mathrm{i}}$ & $17 \pm 0.29$ & $13 \pm 0.17^{\mathrm{e}}$ & $7 \pm 0.29^{\mathrm{b}}$ \\
\hline Kluyveria intermedia & $0 \pm 0^{\mathrm{a}}$ & $0 \pm 0^{\mathrm{a}}$ & $0 \pm 0^{\mathrm{a}}$ & $0 \pm 0^{\mathrm{a}}$ \\
\hline Enterococcus casseliflavus & $13 \pm 0.29^{\mathrm{b}}$ & $11 \pm 0.29^{\mathrm{b}}$ & $8.5 \pm 0.17^{\mathrm{b}}$ & $0 \pm 0^{\mathrm{a}}$ \\
\hline Pseudomonas aeruginosa & $20 \pm 0.29^{f}$ & $15 \pm 0.17^{\text {def }}$ & $13 \pm 0.17^{\mathrm{e}}$ & $8 \pm 0.29^{c}$ \\
\hline
\end{tabular}

Key: $0-10=$ resistant, $11-13=$ intermediate, $\geq 14=$ susceptible. Values are expressed in mean \pm SEM. $P<0.05$ was considered to be statistically significant.

Table 9 Minimum inhibitory concentration (MIC) and Minimum Bactericidal Concentrations (MBC) of extracts on bacterial isolates from RTE foods sold in Akure metropolis

\begin{tabular}{lllll}
\hline ISOLATE & $\begin{array}{l}\text { ETHANOL } \\
\text { EXTRACTS }\end{array}$ & & $\begin{array}{l}\text { WATER } \\
\text { EXTRACTS }\end{array}$ & MBC $(\mathrm{mg} / \mathrm{ml})$ \\
\hline & MIC $(\mathrm{mg} / \mathrm{ml})$ & MBC $(\mathrm{mg} / \mathrm{ml})$ & MIC $(\mathrm{mg} / \mathrm{ml})$ & 50 \\
\hline Salmonella enterica subsp enterica & 50 & 50 & 50 & 25 \\
Enterobacter sakzakii & 25 & 50 & 25 & - \\
Escherichia vulneris & 25 & 25 & - & 25 \\
Pectobacterium carotovorum & 25 & 25 & 25 & 25 \\
Escherichia coli & 50 & 50 & 25 & 100 \\
Serratia liquefaciens & 50 & 50 & 100 & 100 \\
Enteric group 69 & 50 & 50 & 50 & 25 \\
Enterobacter nimipressuralis & 25 & 50 & 25 & 25 \\
klebsiella pnuemoniae & 25 & 25 & 25 & 100 \\
Citrobacter freundii & 50 & 50 & 50 & 50 \\
Salmonella typhi & 50 & 50 & 25 & - \\
Kluyveria intermedia & - & - & - & 50 \\
Enterococcus casseliflavus & 50 & 100 & 50 & 25 \\
Staphylococcus heamolyticus & 25 & 25 & 25 & 25 \\
Kocuria varians & 25 & 25 & 25 & 25 \\
Bacillus cereus & 50 & 50 & 25 & 25 \\
Staphylococcus aureus & 25 & 25 & 25 & 100 \\
Pseudomonas aeruginosa & 50 & 50 & 50 & \\
\hline
\end{tabular}

Quantitative composition of DDPH\% Inhibition, NO\% Inhibition, TBars and \% Iron chelation of water and ethanol extract of Mormordica charantia (Linn) at $100 \mathrm{mg} / \mathrm{ml}$.

Table 10 shows the quantitative composition of DDPH\% Inhibition and Iron chelation analysis in the sun dried water and ethanol extracts of Mormordica charantia (Linn). DDPH\% Inhibition has higher value in the water extract $(69.21 \pm$ $\left.0.882^{\mathrm{a}}\right)$ while lower value was recorded in the ethanol extract $\left(67.89 \pm 0.155^{\mathrm{b}}\right) . \%$ Iron chelation has higher value in the ethanol extract $\left(121.87 \pm 0.882^{\mathrm{a}}\right)$ while lower value was recorded in the water extract $\left(97.28 \pm 0.155^{\mathrm{b}}\right)$.
Table 10 Quantitative composition of DDPH\% Inhibition, NO\% Inhibition, TBars and \%Iron chelation of sun dried water and ethanol extract of Mormordica charantia (Linn) at $100 \mathrm{mg} / \mathrm{ml}$.

\begin{tabular}{llr}
\hline Phytochemicals & Water & Ethanol \\
\hline DPPH\% Inhibition & $69.21 \pm 0.882^{\mathrm{a}}$ & $67.89 \pm 0.155^{\mathrm{b}}$ \\
$\%$ Iron chelation & $97.28 \pm 0.155^{\mathrm{b}}$ & $121.87 \pm 0.882^{\mathrm{a}}$ \\
\hline Means with the same letter within rows are not significantly different at $\mathrm{P} \leq 0.05$ \\
KEY: DPPH - Diphenyl Picryl Hydrazyl Radical
\end{tabular}




\section{Analysis of Vitamin C in Mormordica charantia (Linn)}

Table 11 presents the concentration of vitamin C in Mormordica charantia (Linn). In all the concentration, vitamin $\mathrm{C}$ was higher in the ethanol extract than in the water extract (figure 8).

Table 11 Analysis of Vitamin C in Mormordica charantia (Linn) ABSORBANCE

\begin{tabular}{lclc}
\hline & & & \\
Conc. & \multicolumn{1}{c}{ Vit. C std } & \multicolumn{1}{c}{ Water } & Ethanol \\
\hline $20 \mathrm{mg} / \mathrm{ml}$ & $0.424 \pm 2.646^{\mathrm{a}}$ & $0.414 \pm 2.646^{\mathrm{a}}$ & $0.422 \pm 2.646^{\mathrm{a}}$ \\
$40 \mathrm{mg} / \mathrm{ml}$ & $0.572 \pm 1.155^{\mathrm{c}}$ & $0.433 \pm 1.155^{\mathrm{b}}$ & $0.467 \pm 1.155^{\mathrm{a}}$ \\
$80 \mathrm{mg} / \mathrm{ml}$ & $0.644 \pm 0.882^{\mathrm{c}}$ & $0.476 \pm 1.155^{\mathrm{ab}}$ & $0.480 \pm 0.882^{\mathrm{b}}$ \\
$100 \mathrm{mg} / \mathrm{ml}$ & $0.730 \pm 0.882^{\mathrm{c}}$ & $0.498 \pm 1.155^{\mathrm{b}}$ & $0.492 \pm 2.646^{\mathrm{a}}$ \\
\hline
\end{tabular}

KEY: FRAP - Ferric Reducing Antioxidant Power

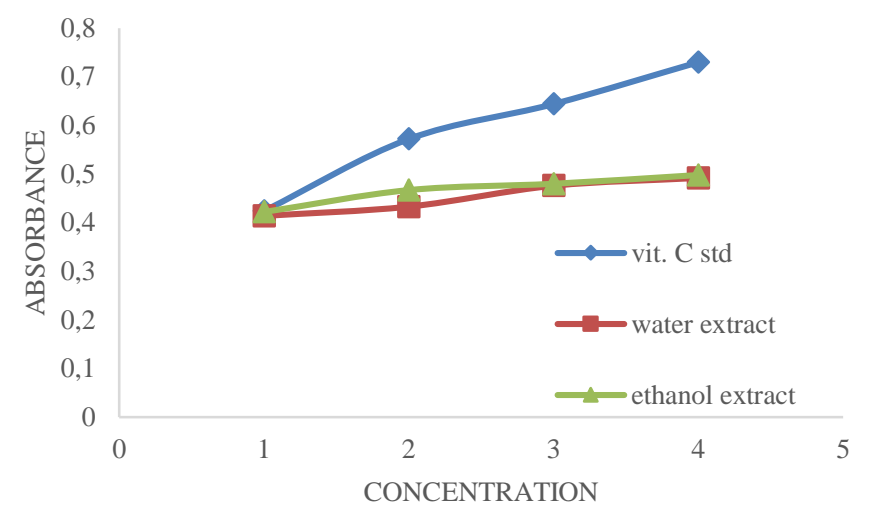

Figure 8 Graphical Representation of Vitamin C in water and ethanol extract of Mormordica charantia (Linn)

\section{DISCUSSION}

The findings in this research indicate that the percentage yields of the extract using different solvents varied. The results corroborate with those obtained by Zaini $\boldsymbol{e t}$ al. (2018) in which the percentage recovery of M. charantia (Linn) varied with different extraction solvents. The $70 \%$ ethanol yielded the highest value of the extract because ethanol is complex chemical structures compared with water extracts. Thus, there was a significant increase in the bioactive substances $(\mathrm{P} \leq$ $0.05)$ from ethanolic extract than water extract respectively and this may be due to the polar nature of ethanol.

The study revealed that all the "ready-to- eat" food had a total bacterial counts that are below potentially hazardous counts according to the International microbiological standards recommended limits of bacteria contaminated for foods which is less than $10^{\wedge} 5 \mathrm{cfu} / \mathrm{g}$ of food for total bacteria plate counts (Owhe-Ureghe et al., 2017).

Bacterial counts obtained and the presence of different species of bacteria in Ready-to-eat food in this study may be attributed to several factors which include the initial contamination on the raw materials to the handling of the finished products. The utensils used in the preparation of the food and sanitary condition of the processing environment especially air and dust-in-air may have contributed to increase in extent of contaminants. The contaminants used up the nutrient in the food, grew and multiplied in their numbers. According to Devi et al. (2016), the total effects of such contaminating factors determines the quality of the food, its probable shelf-life and the potential health risks specially if the contaminants are pathogenic in nature. The result is in harmony with Adewale et al. (2015) that reported different genera of bacteria present in RTE food. Most of the isolates are soil and water microflora, this is however not surprising since soil and water are included among the sources of microbial contaminants in food (Devi et al., 2016). Some of the bacteria isolated are normal flora of man, which are likely to have been introduced by food handlers through sneezing, talking and coughing. The presence of enteric bacteria in the RTE food was not unexpected, however it can be attributed to the water used in preparing the rice by the sellers is most of the time untreated. This points to the fact that not everybody has access to potable water in Nigeria. This study showed that the group of organisms in RTE food in FUTA South gate were prepared under a low standard of hygiene. Some of the microorganisms apart from being able to cause spoilage of the food through their metabolic activities can also pathogenic to the consumers.

The present of some microorganism likes Salmonella enterica subsp enterica, Klebsiella pnuemoniae, Salmonella typhi, Staphylococcus heamolyticus, Bacillus cereus, Staphylococcus aureus e.t.c. occurring in high numbers is of health significance as some of them are known to be associated with food poisoning, infection and intoxication capable of causing various ailments in adults and children which may be fatal.

Commercial antibiotics (standard) were tested against Gram negative and Gram positive isolates respectively. The findings in this research work indicate that the effect of commercial antibiotics (standard) on those isolates varied. Gentamycin $(30 \mu \mathrm{g})$ had the highest inhibition zone for Gram negative bacteria isolates whereas Pefloxacin $(30 \mu \mathrm{g})$ had the lowest effect on Gram negative bacteria isolates. Similar results was obtained by Sharif $\boldsymbol{e t}$ al. (2014) that reported gentamycin to be effective against aerobic gram negative bacteria due to the fact that gentamycin irreversibly binds to the $30 \mathrm{~S}$ ribosomal subunits. Streptomycin $(30 \mu \mathrm{g})$ was effective on all the Gram positive bacteria isolates whereas Ampiclox (30 $\mathrm{g})$ and Pefloxacin $(30 \mu \mathrm{g})$ were effective on one of the gram positive bacteria isolates. This result may be due to the fact that streptomycin is a broad spectrum antibiotics and had two mechanism of action, it can bind to the small 16S of 30 subunits. Moreover, resistance of Kluyveria intermedia to all commercial antibiotics used is worrisome. Unfortunately, resistance of these bacteria to some of this antibiotics is becoming more common globally. As such, appropriate treatment varies with geographic distribution of resistant strains (Mogasale et al., 2021).

It was observed that phytochemical constituents of the ethanolic extract and water extract of M. charantia (Linn) varied. Water extract contained more bioactive compounds than that of ethanolic extracts as indicated by colour change. This result corroborates with the report of Oliveira $\boldsymbol{e}$ al., (2018) that the relative amount of phytochemical substances from plant extraction depends on their solubility in the solvent used for extraction. In this study, Flavonoids and Anthraquinones were absent in both extracts, which could be traced to the choice of solvent, extraction technique, age and specie type (Naqab et al., 2017; Olayinka, 2018). These bioactive compounds that are known to protect the plant against bacterial and fungi in combating bacteria were confirmed in the extracts of sample after phytochemical screening (Amit and Ranjeeta, 2018)

This investigation had shown that the extracts exhibited potent inhibitory potential against the studied bacterial isolate from RTE food. The results revealed that the ethanol and water extracts showed significant to moderate antibacterial activity toward all tested isolates except; Escherichia vulneris and Kluyveria intermedia that are less susceptible to water extracts. Only Kluyveria intermedia is less susceptible to ethanol extracts. The highest inhibitory activity was observed for Bacillus cereus with wide inhibition zone diameters, followed by Escherichia vulneris, Staphylococcus heamolyticus, and Staphylococcus aureus. Since microorganisms differ markedly in their susceptibility, the presence of the active principles in plants is influenced by several factors such as age of the plants, method of extraction and extracting solvent.

The minimum inhibitory concentrations (MICs) of the extracts for the test bacteria were relatively lower in water extract compared to the ethanolic extract. This could probably be due to susceptibility of the bacteria to the extracts after which the extract damages that microbe which is not tolerate to the extracts (Adegbola et al., 2016). Thus water extracts used was more effective against the isolates than ethanolic extracts in this study since a lower MIC value is indicative of the fact that antimicrobial activity against the test pathogenic organism could be achieved at lower concentrations. Results obtained from this study, indicated that, the water extracts showed the strongest antimicrobial activity than the ethanolic extracts. Similar result was was reported by Gonelimali et al. (2018) in which the effectiveness of antimicrobial agent varies with the solvent used and nature of organisms being treated.

At the same concentration, commercial antibiotics were more effective against the bacterial isolates when compared to $M$. charantia (Linn) extracts. This may be as a result of refined materials used in the production of antibiotics. Oladunmoye, M. (2007) reported that antibiotics have high degree of purity; conventional antibiotics and other pharmaceutical products are usually prepared from synthetic materials by means of reproducible manufacturing techniques and procedures expressing purity and high fractionation which certainly will enhance antimicrobial effect than crude extracts.

DPPH\% Inhibition (2,2 - diphenyl - 1 - Picryl - hydrazyl - hydrate) has an antioxidant properties, DPPH\% Inhibition has higher value in the water extract which implies that, The higher the percentage value, the higher the antioxidant 
scavenging ability while lower value was obtained in the etthanol ectract which also implies that the lower the percentage value, the lower the antioxidant scavenging ability. \% Iron chelation has higher value in the ethanol extract which is a therapy that prevents the accumulation of iron reaching harmful levels by matching iron intake from blood transfusion with iron excreted by iron chelation. The higher, the better. Therefore ethanol extract is highly recommended for iron chelation. The analysis of vitamin C in Mormordica charantia (Linn) helps in building immunity against diseases. Result was I harmony with Anjamma $\boldsymbol{e t}$ al., 2018. According to the result obtained Mormordica charantia (Linn) is a good source of Vitamin C. The absorbance which is the FRAP (Ferric reducing antiodant power) was plotted against concentration. FRAP is a reducing agent which is acceptable, it has antioxidant power, it changes $\mathrm{Fe}^{3+}$ to $\mathrm{Fe}^{2+}$. Similar result was repoted by Parra et al., 2021.

This outcome constitutes an encouraging boost for the crude extract, thus paving way for further studies on the plant, as this study of medicinal plants serve as a source of new types of drugs with greater therapeutic activity, lower toxicity, better biocompatibility and more accessibility to the population, which, due to cultural aspects, has a good acceptance, reflecting good prospects in the market of therapeutic products made from active natural Ingredients .

\section{CONCLUSIONS}

The study revealed that all the Ready-to- eat food sold in Akure metropolis had a total bacterial count that are below potentially hazardous count although the presence of some microorganisms that are of health significance were observed, as some of them are known to be associated with food poisoning, infection and intoxication capable of causing various ailments in adults and children which may be fatal.

The study also confirmed that $M$. charantia (Linn) extracts had antibacterial effect against isolated pathogenic bacterial from Ready-to-eat food sold in Akure metropolis, water extracts were found to be more potent being capable of exerting significant inhibitory activities against the majority of the isolates. At the same concentration, commercial antibiotics were more effective against the bacterial isolates when compared to M. charantia (Linn) extracts.

Based on the findings of this great research work, Mormordica charantia (Linn) possesses antioxidant activity that could prevent oxidative stress and degenerative diseases.

The availability and accessibility of $M$. charantia (Linn) being a biological substance, its application would have no or less adverse effect to man and environment, this could make a better alternative to the conventional antibiotics drugs which many pathogens have render less effective due to the development of resistance. This attest that the plant extract could potentiate the development of a new drug against disease caused as a result of food infection or food poisoning.

Recommendation: In order to reduce the incidence of food poisoning and food infection measure such as thorough cooking, the provision of clean food container, using clean wrapping materials and cutleries, serving the food hot to reduce their microbial load as much as practice of basic sanitary rules in preparing foods and good personnel hygiene should be employed. There is need for continuous monitoring of Ready-to- eat food sold in Akure metropolis by the health officers. More research should be conducted using bacterial of different species to further establish reproducibility of the antibacterial potency of $M$. charantia (Linn) as it can be developed into commercial drugs for conventional use, thereby reducing global antibiotics resistance crisis.

List of Abbreviations: FUTA: Federal University of Technology Akure, RTE: Ready-to-eat, DMSO: Dimethylsulfoxide, NA: Nutrient agar.

Authors' contributions: TAI: conceived and designed the experiments, contributed to sample preparation, carried out the experiment, processed the experimental data, performed the analysis, wrote the manuscript, drafted the manuscript, designed the figures and contributed to the interpretation of the results. JOA: involved in planning and supervised the work, contributed to the interpretation of the results, other contribution. All authors discussed the results and commented on the manuscript. All authors read and approved the final manuscript.

Competing interest: the authors declare no Competing interest.

Funding: Not applicable.
Acknowledgements: The Department of Microbiology, School of Life Sciences, Federal University of Technology Akure, Akure Nigeria, is acknowledged for providing the basic infrastructure for carrying out the research work.

\section{REFERENCES}

Adegbola, A, Akinbile, Y, Awotoye, J (2016) Mormodica charantia Linn A potential antibiotic, anti-fungal drug. International Journal of Pharmaceutical Science Invention 5(2):21-27 http://ijpsi.org/Papers/Vol5(2)/E0502021027.pdf

Adewale, O, Olanike, M B, Simeon, K O, Emmanuel, O (2015) Bacteria associated with contamination of ready-to-eat (RTE) cooked rice in Lagos-Nigeria. International Journal of Biological, Chemical Sciences, 9(5): 2324-2333. https://doi.org/10.4314/ijbcs.v9i5.6

Ahn, K (2017) The worldwide trend of using botanical drugs, strategies for developing global drugs. Biochemistry, Molecular Biology Reports, 50(3): 111116 https://doi.org/10.5483/bmbrep.2017.50.3.221

Amit, I, Ranjeeta, K (2018) Phytochemical Screening, anti-microbial activity of $M$ charantia (Linn). International Journal of Pharmacological Research 8(7): 6365 https://doi.org/10.7439/ijpR

Anjamma, N, Lakshmi, Bhavani (2018) Comparative Antibacterial, Antioxidant activity from root, fruit extracts of Momordica charantia (Linn), Momordica dioica. International Journal of Scientific Research in Science, Technology, 4(5):2395-6011 http://dx.doi.org/10.20959/wjpps20192-13111

Awuchi, C G (2019) Medicinal Plants: the Medical, Food, Nutritional Biochemistry, Uses. International Journal of Advanced Academic Research, 5(11): 220-241 www.ijaar.org/articles/Volume5-Number11/SciencesTechnology-Engineering/ijaar-ste-v5n11-nov19-p27.pdF

Banik, A, Maruf, A, Suvamoy, D, Syeda, T (2019) Microbiological Quality of Ready - to - Eat Food from Dhaka, Bangladesh. Current Research in Nutrition, Food Science 7(1): 161-168 http://dx.doi.org/10.12944/CRNFSJ.7.1.16

Boklage, E, Lehmkuhl, M (2018) Coverage of antimicrobial resistance in the German Press: 1993-2013. Journal of Community Health, 34(9):958-63 https://doi.org/10.1080/10410236.2018.1446250

Chokki, M, Zongo, C, Dah-Nouvlessounon, D, Cudalbeanu, M, Noumavo, P, Ghinea, L O, Furdui, B, Savadogo, A, Dinica, R M, Baba-Moussa, L, BabaMoussa, F (2020) Phytochemical screening, antimicrobial activity of Momordica charantia (Linn), Morinda lucida Benth extracts from Benin. African Journal of Microbiology Research, 14(8): 426-435 http://dx.doi.org/10.5897/AJMR2020.9347

Clinical Laboratory Standard Institute (CLSI) (2018) Performance Standards for antimicrobial susceptibity tests Document M100-527 CLSI, Wagne, PA. Clinical Microbiology; 45(1):199-205

Deepti, K, Vijender, S, Mohd, A (2017) Biochemistry, Therapeutic Uses of Medicinal Plants. Discovery Publishing House Pvt Ltd, New Delhi (India), 45(3):978-93

Devi, U, Bharani, A, Sindhura, P, Thejaswi, S (2016) Isolation, Identification Of Pathogenic Bacteria From Hussain Sagar Lake, Hyderabad, Their Antibiotic Sensitivity. European Journal of Biomedical 3(1):238-241 https://www.ejbps.com/ejbps/abstract id/790

Gonelimali, F, Jiheng, L, Wenhua, M, Jinghu, X, Fedrick, C, Hatab, S (2018) Antimicrobial Properties, Mechanism of Action of Some Plant Extracts Against Food Pathogens, Spoilage Microorganisms. Frontier Microbiology 9:1639 http://dx.doi.org/10.3389/fmicb.2018.01639

Guarniz, W, Canuto, K, Ribeiro, P, Dodou, H, Magalhaes, K, Sa, K (2019) Momordica Charantia L variety from Northeastern Brazil : Analysis of Antimicrobial Activity, Phytochemical Components. Pharmacognosy Journal, 11(6):1312-24 http://dx.doi.org/10.5530/pj.2019.11.203

Jandari, S, Abed, G, Rahele, Z, Nattagh-Eshtivani, E, Mohammadi, H (2020) Effects of Momordica charantia L on blood pressure: a systematic review, metaanalysis of randomized clinical trials. International Journal Of Food Properties, 23(1):1913-1924 http://dx.doi.org/10.1080/10942912.2020.1833916

José, G, Adriana, R, Fabíola F, Rodrigues (2015) Antibacterial activity of Momordica charantia (Curcubitaceae) extracts. Fractions Journal of Basic, $\begin{array}{lll}\text { Clinical Pharmacy 2(1):23-123 } & \end{array}$ www.ncbi.nlm.nih.gov\%2Fpubmed\%2F24826002

Khalid, Z, Hassan, S, Shahzad, S, Khurram, H (2021) A Review on Biological Attributes of Momordica charantia. Advances in Bioscience, Bioengineering, 9(1): 8-12 http://dx.doi.org/10.11648/j.abb.20210901.12

Madueke, S N, Awe, S, Jonah, A (2014) Microbiological analysis of street foods along Lokoja-Abuja Express Way, Lokoja. American Journal of Research Communication, 2(1): 196-211. www.usa-journals.com/wpcontent/uploads/2014/01/Madueke_Vol21.pdf 
Mboto, C I, Agbo, B E, Ikpoh, I S, Agbor, R B, Udoh, D I, Ambo, E E, Ekim, M A (2012) Bacteriological study of raw meat of Calabar Abattoir with public health, veterinary importance. Journal of Microbiology, Biotechnology Research, 2(4):529-532

Mogasale, V, Saldanha, P, Pai, V (2021) A descriptive analysis of antimicrobial resistance patterns of WHO priority pathogens isolated in children from a tertiary care hospital in India. Scientific Report 11:5116 http://dx.doi.org/10.1038/s41598021-84293-8

Muronga, M, Cristina, Q, Phumudzo, P, Tshikhudo, A, Ahmad, F (2021) Three Selected Edible Crops of the Genus Momordica as Potential Sources of Phytochemicals: Biochemical, Nutritional,, Medicinal Values. Journal of Pharmacy, Pharmacognosy Research, 9 (4):537-548, http://dx.doi.org/10.3389/fphar.2021.625546

Naqab, K, Abdulhaleem, S, Ejaz, A K, Muhammad, S, Samiullah, K, Natasha, B (2017) Phytochemical analysis, biological activities of stem bark extract of Jatropha curcas L. International Journal of Pharmacognosy 2:155-168

New South Wales (NSW) (2019) Food Authority: www.foodauthoritynsw.gov.au [Retrieved November 15, 2020]

Oladunmoye, M K (2007) Comarative evaluation of antimicrobial activities of leaf extract of Mirabilis jalapa, microbial toxins on some pathogenic bacteria. Trends in Medical Research 2 (2): 108-112 http://dx.doi.org/10.3923/tmr.2007.108.112

Olayinka, T O (2018) Phytochmicals- God's endowment of curative power in plants. Phytochemicals-Source of Antioxidants, Role in Disease Prevention, 12:112 https://www.intechopen.com/chapters/61539

Oliveira, M, Wanessa, A, Fernanda, W, Marilena, E, Raul, F (2018) Phytochemical profile, biological activities of Momordica charantia L (Cucurbitaceae): A review African Journal of Biotechnology 17(26):829-846 https://doi.org/10.5897/AJB2017.16374

Olusola-makinde, Olabanji, OB, Ibisanmi, TA (2021) Evaluation of the bioactive compounds of Vernonia amygdalina Delile extracts and their antibacterial potentials on water-related bacteria. Bulletin of the National Research Centre 45(1):191 http://dx.doi.org/10.1186/s42269-021-00651-6

Owhe-ureghe, U B, Ekundayo, A O Agbonlahor, D E, Oboh, P A, Orhue, P (1993) Bacteriological examination of some Ready-to-eat foods marked in Ekpoma, Edo state of Nigeria. Nigeria Food Journal, 11: 45-52 www.iosrjournals.org/iosrjestft/papers/vol8-issue9/Version-1/L08918192.pdf

Owusu, E, Ahorlu, M, Afutu, E, Akumwena, A, Asare, G (2021) Antimicrobial Activity of Selected Medicinal Plants from a Sub-Saharan African Country against Bacterial Pathogens from Post-Operative Wound Infections. Journal of Medical Scence, 9:23 https://doi.org/10.3390/medsci9020023

Palomino, JC, Martin, A, Portaels, F (2007) rapid drug resistance detection in Mycobacterium tuberculosis: a review of colorimetric method. Clinical Microbiology, Infection, 13:754-762 https://doi.org/10.1111/j.14690691.2007.01698.x

Parra, A, Roberto, M, Piloto, F, Pham, T, Nguyen, P, Addis, B, Gilberto, L (2021) Antidiabetic,hypolipidemic, antioxidant, anti-inflammatoryeffects of Momordica charantiaLfoliage extract. Journal of Pharmacy, Pharmacognosy Research, 10(4):647-653 https://jppres.com/jppres/pdf/vol9/jppres21.1018_9.4.537.pdf Samuel, P, Joan-Miquel, B, Amanda, H, Robert, C (2016) Multicenter Assessment of Gram Stain Error Rates. Journal of Clinical Microbiology 54:6 http://dx.doi.org/10.1128/JCM.03066-15

Sharif, A, Mohammad, R, Alizargar, J (2014) Antibiotic Resistance of GramNegative Bacteria to Ampicillin, Gentamicin, Imipenem in Samples of the Patients Admitted to Shahidbeheshti Hospital in Kashan World Applied Sciences Journal 30 (6): 778-781 http://dx.doi.org/10.5829/idosi.wasj.2014.30.06.82327

Shubha, AS, Devaraju, Sharavati MB, Srinivasa, V, Kantharaj, Y, Ravi, CS, Akshay, Angadi, Yallesh, kumar, HS, Shanwaz, Ahmed (2018) Medicinal, nutritional importance of bitter melon ( $M$ charantia (Linn)). Journal of Pharmacognosy, Phytochemistry, 297-300 https://www.phytojournal.com/archives/2018/vol7issue3S/PartH/SP-7-3-47-

$\underline{591 . p d f}$

Sofowora A (1995) Medicinal, Traditional medicine in Africa (Second edition) Spectrum Books Limited, Ibadan, Nigeria pp130

Şükriye, S, Beytullah, K (2014) Assessment of microbiological quality of readyto-eat foods in Istanbul, Turkey. Journal of Food Agriculture, Environment 12: 3$4 \mathrm{http}: / / \mathrm{www}$. globalresearchjournals.org/?a=journal\&id=grjm

Thiyam, B, Sharma, G (2013) Isolation, identification of fungi associated with local fruits of barak Valley. Current World Enviroment International Research Journal 8(2):319-322 http://dx.doi.org/10.12944/cwe.8.2.20

United Kingdom Standard for Microbiology Investigation (USMI, 2018) Methods for Antimicrobial Dilution, Disk Susceptibility Testing of Infrequently Isolated or Fastidious Bacteria Methods for Antimicrobial Dilution, Disk Susceptibility
Testing of Infrequently Isolated or Fastidious Bacteria. United Kingdom Standard for Microbiology Investigation 15(3):1-32 https://clsi.org/media/1450/m45ed3 sample.pdf

Villarreal-La, T, Sagástegui, G, Silva-Correa, C, Cruzado-Razco L, Siche R (2020) Antimicrobial Activity, Chemical Composition of Momordica Charantia: A Review. Pharmacognosy Journal 12(1):213-222 http://dx.doi.org/10.5530/pj.2020.12.32

Zaini, A, Noor, A, Nicky, R, Syafiza, A, Mohd Johari, K, Zuhaili, I, Mohd, A (2018) Comparison of charantin extract from M charantia (Linn) using modified supercritical carbon dioxide, soxhlet extraction method. Malaysian Journal of Fundamental, $\quad$ Applied $\quad$ Sciences $4: 462-466$ http://dx.doi.org/10.11113/mjfas.v14n4.1092 